\title{
Implementation Challenges of Land Redistribution Programme in South Africa
}

\author{
Nwabisa Tyekela, Christopher Amoah* \\ Department of Quantity Surveying and Construction Management, University of the Free State, Bloemfontein 9300, South \\ Africa
}

Corresponding Author Email: amoahc@ufs.ac.za

https://doi.org/10.18280/ijsdp.160713

Received: 18 March 2021

Accepted: 19 October 2021

\section{Keywords:}

challenges, land redistribution, implementation, programme, South Africa

\begin{abstract}
Upon assuming political office, the ANC government instituted a land redistribution programme to address the land ownership injustice perpetrated during the apartheid regime whereby the non-white citizens owned only $7 \%$ of land in South Africa. However, the programme has not achieved the set target; thus, this study sought to understand the challenges curtailing the successful implementation of the programme. The study used a qualitative research approach. An in-depth interview was conducted with three purposefully selected senior officials from three Departments in Greater Kokstad Municipality involved in the land redistribution programme's implementation. The findings indicate that the major issues curtailing the programme's implementation are land claim disputes and mediation process, reliance on the willing-seller-willing-buyer model, lack of institutional capacity, cumbersome beneficiary selection process, land beneficiary resettlement support, and inadequate programme's monitoring and evaluation. There is an urgent need for the government to institute measures to address the challenges preventing the smooth implementation of the land redistribution programme in South Africa. These challenges prevent the programme's beneficiaries from accessing the land, thus preventing them from experiencing socio-economic emancipation as promised.
\end{abstract}

\section{INTRODUCTION}

When the ANC took over in 1994, the land issue was already on the table, amongst other things that the government had to address. The democratic government has made significant strides in handling many different issues, such as providing social services (i.e., water, access to health services, electricity, and housing) [1]. However, despite this outstanding performance, the ANC government's scorecard on ensuring tenure security has been the weakest, as progress in this area has been slow [1-3].

The enactment of the Natives Land Act of 1913 provided a mechanism for the apartheid government to dislodge black communities and confine them to rural reserves, which constituted only $7 \%$ of the country's land. However, this was later increased to $13 \%$ with the implementation of the Natives Trust and Land Act of 1936 [3]. In trying to reverse this disenfranchisement, the ANC government promulgated the White Paper of South African Land Policy [4]. The key driving force of the White Paper was the fact that ownership of land and development still reflected the economic and political conditions of the apartheid dispensation [4]. These patterns resulted in insecurity of tenure, landlessness, and poverty amongst the majority of black people. The success of the land policy, thus, was to be measured against these variables. Rigorous land reform must improve people's conditions of life and remove barriers that make access and land ownership difficult for disadvantaged sections of society [5].

Section 25 of the Constitution places an obligation on the state to ensure that citizens are enabled to gain equitable access to land, ensure the security of tenure and redress the effects of dispossession after 19 June 1913 as a result of past discriminatory laws or practices [6]. However, after more than two decades of democratic rule, many people dispossessed with their land are still waiting for redress. For instance, the ANC government has instead set Section 25 of the Constitution to explain the lethargic fulfilment of the promise of equitable access to land [7]. President Cyril Ramaphosa has set out the vision for the land reform as follows:

"We will accelerate our land redistribution programme not only to redress a grave historical injustice but also to bring more producers into the agricultural sector and to make more land available for cultivation ... this approach will include the expropriation of land without compensation. We are determined that expropriation without compensation should be implemented in a way that increases agricultural production, improves food security and ensure [s] that the land is returned to those from whom it was taken under colonialism and apartheid." [8].

Although the promise set out by the President above seems new, it is not new as the White Paper of South African Land Policy made a similar promise [4], as follows:

"The purpose of the Land Redistribution Programme is to provide the poor with land for residential and productive purposes in order to improve their livelihoods. The government provides a single, yet flexible, redistribution mechanism which can embrace the wide variety of land needs of eligible applicants. Land redistribution is intended to assist the urban and rural poor, farmworkers, labour tenants, as well as emergent farmers. " [4]. 
The introduction of the land redistribution programme was meant to ensure that tenure is secured for the beneficiaries and that the land is utilized to establish productive agricultural enterprises and a settlement for residential purposes. Central to this initiative was to improve the socio-economic conditions of the beneficiaries. From the above, it is essential to understand the challenges hindering the land redistribution programme's implementation, hence the need for this study.

\section{LITERATURE REVIEW}

\subsection{Land reform issues in South Africa: A brief history}

The degree to which SAs indigenous people experienced dispossession at the hands of the European (mainly British and Dutch) colonialists was far greater than in any other African country - and it lasted for an exceptionally prolonged time [9]. In fact, Moseley and McCusker [10] affirm that given all the examples of the unequal distribution of land globally, SA is effortlessly one of the most severe cases of a land imbalance concerning the population. As a consequence of anti-apartheid campaigns, the apartheid-era land concentration statistics became general knowledge: the majority of the people, $70 \%$ to be exact, remains currently cramped in roughly $13 \%$ of the overall land area of SA [11]. The elements that shaped this skewed distribution of land were not only the Afrikaaner-led nationalist government's programmes (1948-1994); however, it also resulted from over three centuries of land dispossession in favour of the white-minority colonists [12].

Moreover, European settlement started in the early 1650s following the Dutch East India Company's arrival at the Cape of Good Hope; it then spread eastward and northward over 300 years [13]. By the dawn of the $20^{\text {th }}$ century, large portions of the country's land; mainly, the majority of the prime agricultural land had already been earmarked for the white minority population. However, the vast numbers of Africans remained restricted to "Native Reserves" (later called Bantustans or African Homelands), which accounted for a fractional percentage of the country's land [13]. Following the 1960s, the settler colonies within Southern Africa went to great lengths to resist the then ubiquitous movements to decolonize Africa, which led to SA not transitioning from the race-based apartheid regime to a democratic, all-inclusive system of governance until 1994 [13].

According to the Republic of South Africa [6] contrary to most other countries that possessed unequal land allocation, SAs history is wrought with particularly racially-biased policies, has obvious implications for the ownership of land and its distribution [14]. SA's heritage of inequity was cemented by enacting two very well-known Acts: The Natives Land Acts of 1913 and 1936. In particular, the apartheid government legalized land dispossession through the Natives Land Act of 1913 [6]. The former Act (of 1936) limited land ownership by indigenous people to $7 \%$, giving white people effective control over $93 \%$ of the land in SA [15]. Also, the latter Act (of 1936) made further provision for a mere 13\% of SA's land to be reserved for non-whites - who also happened to represent the majority (roughly 90\%) of the country's population [14].

According to the World Bank [16], SA experienced extreme inequalities in land distribution due to spatial segregation measures. In addition to the imposed restrictions on indigenous farmers' farming activities, such land inequity gave life to deeply entrenched inequalities between the indigenous and white farmers [6]. By 1994, following the first South African democratic elections, some 60,000 white farmers inhabited 87 million hectares of privately owned land [17]. According to the World Bank [16], these commercial farms' contributions amounted to roughly $95 \%$ of SA's aggregate agricultural produce and guaranteed the country self-sufficiency in many agricultural goods.

Therefore, land reform formed part of the ANC's many key promises when it assumed power in 1994 [18]. One of the rationales behind the formulation and subsequent implementation of the Reconstruction and Development Programme (RDP) was the Land Reform Programme's significance in redressing the historical injustices resulting from the involuntary evacuations and restrictions upon access to land [18]. To resolve overcrowding in specific rural areas within the former Bantustans and Reserves as well as to promote the accessibility of both farm and residential land, the land reform programme was recognized as the government's centrepiece for growth, employment, and redistribution (i.e., the GEAR strategy) [18]. This latter strategy was founded upon the premise that the SAs land reform process is not merely a crucial feature of the country's socio-political transition but a prerequisite condition regarding the country's social, economic, and political stability of the country [14]. Accordingly, the ANC intended to redistribute $30 \%$ of SA's land in the first five years of being in the office [18]. As would be expected, this, however, necessitated the implementation of modified economic policies [14]

Moreover, during the initial land redistribution conference in SA, convened in Johannesburg in 1993, the then ANC secretary-general, now president Cyril Ramaphosa, made a point that SA is not exactly exclusive in its inequitable distribution of land; rather, it is unique in the form of policies and programmes which moulded the situation [18]. Additionally, SA's new Constitution, finalized in 1996, laid the foundation for a somewhat more liberal democracy. However, it also stressed the importance of socio-economic rights and placed an unambiguous mandate upon the state to redress the past imbalances [9]. The Constitutional clause on property guarantees the land rights of the incumbent landowners; however, it further obliges the state to take reasonable steps to enable citizens to gain equitable access to land and promote tenure security [6]. The Constitution further permits specific rights of redress to those who were dispossessed of property after 19 June 1913 due to discriminatory laws and practices and therefore set a legal foundation for a potentially effective land reform strategy/programme [9].

\subsection{Land reform challenges in post-apartheid South Africa}

The ANC government faced a catalogue of challenges emanating from the legacy of apartheid when it was democratically elected into power in 1994 [19]. For instance, it dawned on the ANC that, if it were serious about a better life for all, it had to reverse the exclusion of black South Africans from the private property ownership system [19]. In reality, the democratic government had to bridge the terrible gap that white South Africans possessed to secure individual tenure and title to their properties whilst their indigenous counterparts had insecure rights to land [7]. Through its White Paper on South African Land Policy, the democratic government articulated its policy direction regarding the issue of security 
of tenure:

"Redistributive land reform cannot in itself ensure national economic development, but it is a necessary condition for a more secure and balanced civil society. It is an essential precondition for the success of the government's growth, employment and redistribution strategy. In contributing to conditions of stability and certainty, land reform is a necessary element of sustainable growth." [4].

The implication in the above statement is that the democratic government viewed the land reform process as a mechanism for bringing about sustainable and equitable growth of the country's economy; thus, land access was considered a cultural, political, and economic issue. Essentially, the land was seen as a critical enabler for effective participation in the mainstream of the country's economy [20]. However, the major challenge facing this dream was that the narrative of land reform within a country (SA) which conformed to a dominant narrative of liberal market imperatives, as is demonstrated in the extract from the White Paper below:

"The government is committed to a land reform programme that will take place on a willing-seller-willing-buyer basis. Rather than become directly involved in land purchase for the land redistribution programme, the government will provide grants and services to assist the needy with the purchase of land." [4].

Ironically, the policy that was supposed to serve as a mechanism for ensuring equitable access to land for all willingly embraced the principle of willing-seller-willingbuyer, recommended by the World Bank - was the very obstacle that would later impede the effective redistribution of land [20]. In reality, however, this conformity to liberal market ideologies reduced the transformative agenda into a mere outcome of markets and severely restricted the state's role in redistributing land equitably [20]. In other words, the direction taken by the democratic state reinforced the historical or currently existing inequitable patterns of access to land. Regarding perspectives on the delivery of the promise of land, the democratic government set itself a target of $30 \%$ redistribution of the white-owned agricultural land by 2014/15 [21]. However, by 2016, the state had only redistributed $5.46 \%$ of commercial farmland [21]. The High-Level Panel on the Assessment of Key Legislation and the Acceleration of Fundamental Change, which was tasked with the responsibility of evaluating state policy and its ability to fulfil delivery targets, and make recommendations to improve state capacity, remarked as follows, regarding the land redistribution programme:

"There are still 7,000 unsettled, and more than 19,000 incomplete, 'old order' claims (claims lodged before the initial cut-off date of 1998). At the present rate of finalizing 560 claims per year, it will take at least 35 years to finalize all 'old order' claims; new order claims (lodged in terms of the nowrepealed Restitution of Land Rights Amendment Act of 2014) that have already been lodged will take 143 years to settle; and if land claims are re-opened and the expected 397,000 claims are lodged, it will take 709 years to complete Land Restitution." [21].

The above report points to the inefficient and unsustainable manner in which the policy on land redistribution has been implemented. In addition, the High-Level Panel on the Assessment of Key Legislation and the Acceleration of Fundamental Change also remarked that the Land Claims Commission, which its primary basis is to manage land claims and the redistribution process, has been inefficient and dysfunctional:

"Implementation has been poor at every level. Whilst the budget has been criticized for not being high enough to cover the costs of restitution (for example purchasing [the amount of] land required) the Commission has consistently underspent the budget, suggesting that the fundamental problems lie with capacity and systems. Choices around spending have been poor. There has been political meddling in land restitution, both in terms of unreasonable targets for redistribution, as well as in terms of individual restitution awards, which has damaged the integrity of the process." [21].

Alexander [20] has argued that part of the problem of the unfulfilled promise of the delivery of land has been the characterization of landlessness as homelessness. For instance, the government has acknowledged the landless "as having land needs insofar as they needed land for building homes, but not necessarily for other purposes" [20]. Alexander [20] further remarks that the government's obsession with pleasing markets has been central to this trajectory. The question that this raises for this study is whether the meaning and experience of being a beneficiary of the land redistribution programme have transcended the need for land for building homes?

\subsection{Land redistribution programme: Global perspective}

Kinsey [22] argues that a more significant majority of the citizenry have not succeeded in realizing the intended forecasts in neither productivity nor production since they possessed insufficient means to transform such resources (land) into an improved livelihood or enhanced household welfare standards. Moreover, Chimhowu [23] adds that access or transfer of land without sufficient post-transfer support may leave them vulnerable for most poor households in Zimbabwe. According to Chimhowu [23], the Expenditure Survey of 1995 found the scourge of poverty most prevalent amongst resettled farmers. The survey stressed that land reform or 'assetting' had failed to lift vulnerable households from poverty.

In a Latin American study conducted by López and Valdés [24], using income to land elasticity estimates for 8 Latin American countries, the income-generating potential for land seemed negligible for these eight sampled countries. Likewise, Deininger and Binswanger [25] also suggest that land reform beneficiaries in Zimbabwe can expect to experience a Z\$165 per annum increase in their per capita expenditures. In a similar study that seeks to examine the agricultural land reform's impact on the Korean economy, Jeon and Kim [26] discover that economic growth and agricultural production were affected somewhat favourably by abolishing the tenancy system in rural Korea. They also found that the land reform redeployed income from landlords to tenants; however, the general public and government also benefited from it.

Just like Antwi and Oladele [27] and Jeon and Kim [26], Jayne et al. [28] find the following: concerning the relationships between land and income inequality for each surveyed country (i.e., Rwanda, Ethiopia, Kenya, Zambia, and Mozambique), they discovered the existence of a positive correlation between household per capita land holdings and per capita income (the total of livestock, non-farm, and farm income). The Jayne et al. study supports Dikgang and Muchapondwa [29] study conducted in India, which uncovered visible improvements in the alleviation of rural poverty and other related rural economic aspects due to the adoption of land reform programmes. In a related study, 
Chirwa [30] examines the performance of agricultural investments, productivity, and food production following a land reform programme implementation in Malawi. The author concludes that, of those smallholder farmers able to partake in the community-based land development programme, they tend to have better overall welfare and also tend to be more productive than non-participants - this is largely because they are able to gain increased access to land and capital resources, and thus are more likely to buy enhanced maize seeds [30]. On further investigation, the econometric results revealed that the latter positive effects were driven mainly by access to financial resources and not the change in land tenure per se [30]. Chirwa [30] and Byamugisha [31] arrive at the same conclusion, which acknowledges the importance of having complementary financial assistance for land reform programmes to have any noticeable impact on poor smallholder farmers.

Albeit, Benin and Pender [32] claim that even though land redistribution is such a heavily debated topic, there is still insufficient evidence regarding the actual influences of land redistribution from Africa's perspective. For instance, in the Amhara region (Ethiopia), land redistribution has had a relatively positive effect on land productivity through improved access to land for farmers who are willing and capable of purchasing inputs such as herbicides fertilizers [32].

\subsection{The challenges of land redistribution in South Africa}

There are various reasons why any country might wish to adopt some particular form of a land reform programme. According to Deininger and Binswanger [25], such reasoning could range from preventing social turmoil and lessening poverty to relieving political pressure from peasants and augmenting productivity. In SA, however, the post-apartheid government (i.e., the ANC) has decided to embark on land reform programmes that go much deeper than those cited above [33]. As stated above, in SA, the issue of land dates as far back as 1913 and 1936 when the then National Party government adopted the Natives Land Act of 1913 and the Natives Land and Trust Act of 1936 [33]. Following SA's 1994 democratic elections, the ANC, which was elected into power, vowed to redress the past's imbalances, such as those on the unequal distribution of land [18]. According to Binswanger and Elgin [34], a land reform programme can typically be deemed successful if it improves the beneficiaries' income, consumption, and wealth - of course - amongst many other socio-economic variables.

Anseeuw and Mathebula [18] conducted a municipal-level study to investigate the existence of any correlation between development and land reform within the Mole-mole Municipality in SA. Anseeuw and Mathebula's [18] study contained all the 42 land reform projects currently underway within the selected study area and found that, although all of the farms were profitable, they could not achieve effective growth, some experiencing drops in production levels. Thus, these farms are having a difficult time developing and maintaining their agricultural production. Another study in SA by Moseley and McCusker [10] revealed "no significant benefit to the livelihood systems of participants that could be linked directly to land redistribution projects since numerous indicators seemed to depict either zero or limited impact on the economies of households. In fact, interviewees advocated that the programmes were "depleting social capital and increasing the conflict" [10].
Lahiff and Li [9] provide an overview of SA's land reform from 1994 to 2011 - with a particular focus on land redistribution and cite that there exist a plethora of reasons as to why government policies and the associated execution thereof has failed to produce the expected socio-economic outcomes since 1994. They further add that, due to poor project designs, a shortage of support services, and working capital constraints, it has resulted in a minimal impact on the livelihoods of beneficiaries - irrespective of them having received land [9]. Therefore, they conclude that no evidence exists to suggest that any improvements in employment, income, economic growth, and agricultural efficiency have materialized due to land redistribution within these two South African provinces [9]. A study tracking land redistribution failures by Dikgang and Muchapondwa [29] concluded that distributed land negatively affects per capita income and contributes to aggravated poverty.

\section{RESEARCH METHODOLOGY}

\subsection{Research approach}

A qualitative research approach was adopted for the study. According to Blumberg et al. [35], the qualitative research approach is described as discovering and understanding the significant groups or individual's social problems. Typically, the research procedure entails emergent processes and questions, data collected within the setting of the participants, data analysis involving inductive construction from specific to general themes, and the provision of interpretations of the essence of the data by the researcher [36]. Creswell and Creswell [37] highlights that those researchers who are inclined to this style of inquiry adhere to a research perspective that advocates an inductive style, the significance of representing the intricacy of a situation, and a concentration on individual meaning. Thus, a qualitative research approach was adopted for this study because it delves into how the research participants understand and make sense of their experiences in implementing the land redistribution programme [36].

\subsection{Sampling design}

Therefore, the sampling or selection of participants was purposive in that the selection was guided by specific criteria that would lead to a particular set of participants [38]. The research focuses on the government officials from the Department of Agriculture, the Department of Rural Development and Land Reform, and the local economic development section of the municipality in the Greater Kokstad Municipality area. Also, the selected musicality has embarked on the land redistribution programme, and these departments are kingly involved in implementing the programme. Thus, one senior person from each of these departments tasked to facilitate the programme implementation was sampled for an interview as they would have an in-depth understanding of the research phenomenon.

\subsection{Data collection tool}

The in-depth semi-structured interviews were conducted with key senior officials and representatives from the Department of Agriculture, the Department of Rural 
Development and Land Reform, and the Local economic development section of the municipality. The selection of the semi-structured interview for this study was based on the belief that it potentially provides an opportunity for the researcher to eliminate questions that were ineffective in providing information necessary for the study [39]. This means that semi-structured interviews allow the researcher to follow up with new issues as they emerge. The semi-structured interviews were conducted with the assistance of an interview guide. The interview guide's significance is in its potential to set out "a listing of matters to be sure to ask about" [40]. The members were interviewed one by one to grant the researcher time to mirror what had emerged from the interviews. A duration of 45 minutes was allocated to each participant, and interviewees were allowed to respond in the language they would be most at ease with. The purpose of this was to ensure that interviewees do not have to battle with language in sharing their experiences.

\subsection{Data analysis}

The thematic content analysis approach was used to analyze the collected data. It is believed that this approach enables the researcher to scrutinize transcriptions of recorded information [41]. The content analysis of data involves making sense of textual qualitative materials to construct and/or support a particular argument line [41, 42]. Participants were quoted verbatim in the discussions. The profiles of the three officials interviewed are indicated in Table 1

\subsection{Nature of the interviewees}

Table 1 summarizes the interviewees from the three departments involved in implementing the land redistribution programme in the Greater Kokstad Municipality.

Table 1. Study participants

\begin{tabular}{ccc}
\hline Participants & Position & Code \\
\hline 1 & $\begin{array}{c}\text { Senior Official - Department of } \\
\text { Agriculture }\end{array}$ & DA1 \\
2 & $\begin{array}{c}\text { Senior Official - Department of } \\
\text { Rural Development and Land } \\
\text { Reform }\end{array}$ & DRDLR1 \\
& $\begin{array}{c}\text { Senior Manager - The Local } \\
\text { Economic Development section of } \\
\text { the municipality }\end{array}$ & MM1 \\
& & \\
\hline
\end{tabular}

\section{FINDINGS}

\subsection{Participants responses to the interview questions}

Table 2 indicates the various views expressed by the participants based on the questions asked during the interview.

Table 2. Participants responses to the interview questions

\begin{tabular}{|c|c|c|c|}
\hline Question asked & Participant 1 (DA1) & Participant 2 (DRDLR1) & Participant 3 (MM1) \\
\hline \multirow{7}{*}{$\begin{array}{l}\text { What are the major } \\
\text { challenges faced by the } \\
\text { government with the land } \\
\text { redistribution programme? }\end{array}$} & \multirow[b]{2}{*}{$\begin{array}{l}\text { Land claim disputes, } \\
\text { resolution, and } \\
\text { mediation }\end{array}$} & $\begin{array}{l}\text { Reliance on the Willing-seller- } \\
\text { willing-buyer Model for Land } \\
\text { Redistribution }\end{array}$ & $\begin{array}{l}\text { Reliance on the Willing- } \\
\text { seller-willing-buyer Model } \\
\text { for Land Redistribution }\end{array}$ \\
\hline & & Land Claims Disputes & \\
\hline & \multirow{5}{*}{$\begin{array}{c}\text { Land Redistribution } \\
\text { Beneficiary Selection } \\
\text { Process }\end{array}$} & Institutional Capacity to Ensure & \\
\hline & & Effective Land Redistribution & \\
\hline & & $\begin{array}{c}\text { Land Beneficiary Resettlement } \\
\text { Support }\end{array}$ & \\
\hline & & $\begin{array}{c}\text { Land Redistribution Beneficiary } \\
\text { Selection Process }\end{array}$ & \\
\hline & & $\begin{array}{l}\text { Monitoring and Evaluation of } \\
\text { the Land Redistribution } \\
\text { Programme }\end{array}$ & $\begin{array}{l}\text { Monitoring and Evaluation } \\
\text { of the Land Redistribution } \\
\text { Programme }\end{array}$ \\
\hline \multirow{2}{*}{$\begin{array}{l}\text { What support is given to } \\
\text { beneficiaries pre-, during- } \\
\text { and post-land transfers by the } \\
\text { government? }\end{array}$} & $\begin{array}{l}\text { Supply of food to } \\
\text { claimants }\end{array}$ & \multirow[t]{2}{*}{ Feeding scheme } & $\begin{array}{c}\text { Temporarily } \\
\text { accommodation }\end{array}$ \\
\hline & $\begin{array}{l}\text { Funding for farm } \\
\text { equipment } \\
\text { Training }\end{array}$ & & Training \\
\hline \multirow{2}{*}{$\begin{array}{l}\text { What role does the } \\
\text { government in ensuring } \\
\text { equity and fairness in the } \\
\text { land restoration exercise for } \\
\text { effective land redistribution? }\end{array}$} & $\begin{array}{l}\text { pre-agricultural } \\
\text { assessment and } \\
\text { assistance }\end{array}$ & $\begin{array}{l}\text { pre-lodgment-of-claim skills } \\
\text { assessment }\end{array}$ & \\
\hline & & Business plan implementation & mentorship programmes \\
\hline
\end{tabular}

\section{DISCUSSIONS OF THE FINDINGS}

\subsection{The major challenges faced by the government with the land redistribution programme}

This objective intends to identify some of the major challenges that the state and its officials face in implementing the land reform and redistribution programs. The state officials interviewed identified the following as the major obstacle they encountered with implementing the programmes.

5.1.1 Reliance on the Willing-seller-willing-buyer Model for Land Redistribution

Both interviewed government respondents (MM1 and 
DRDLR1) held a unanimous view that the current freemarket-based willing-seller-willing-buyer model results in massive delays concerning effective negotiation of land prices with current landowners. Lahiff's [43] study cites that even the landowners criticize this model primarily for its slow payments and cumbersome bureaucracy. However, they still adhere to it since it puts the breaks on the pace of land reform and provides greater levels of proceeds than they would otherwise receive under a different programme [43]. The latter discovery is also consistent with Alexander [19], who states that the SA government adopted the World Bank recommended a willing-seller-willing-buyer model, which would later sabotage the expeditious redistribution of land in SA. As one state official (DRDLR1) states:

"The current free-market based willing-seller-willingbuyer approach results in huge delays with regards to effectively negotiating land prices with current landowners."

\subsubsection{Land claims disputes}

A government respondent (MM1) argued that land claim disputes are a long process to mediate and resolve. Also, they cited that rural land claims - such as those of the GKM - are affected by some of the following obstacles:

(1) Land claim disputes, resolution, and mediation: this is typically a lengthy and time-consuming procedure that often results in protracted delays in the land restitution processes.

(2) Untraceable claimants: the major reason for claimants who are difficult to trace or sometimes even untraceable is that many claimants are still residents within informal settlements - with no formal house address.

(3) Lack of technical and financial support: this again emphasizes the absence of institutional capacity within the state institutions tasked with the mediation and resolving land claim disputes.

(4) Land price negotiations with current landowners: existing white land farmers or owners have, many times, been alleged to tend to inflate the present value or price of the land they wish to sell, and this forces the government to enter into negotiations with those farmers.

(5) High land prices and disputes around land valuation: this point is related to the one above - in fact, the conflicts herein are frequently the result of the failure to reach an agreeable purchase price.

(6) Boundaries disputes among traditional leaders: these generally stem from ancient, ongoing struggles for either territorial gain or domination by one clan over the other.

(7) Disputes with landowners on the validity of claims, land prices, settlement models, and conditions: these disputes typically relate to disagreements between current white landowners, farmers, or claimants against indigenous claimants to the same land.

(8) Conflict amongst traditional leaders, the community, trusts, and beneficiaries: the last forms of disputes are probably the most complex but avoidable. They mainly entail issues of corruption and distrust amongst traditional leaders as well as the communities they govern.
5.1.3 Institutional capacity to ensure effective land redistribution

A government respondent (DRDLR1) stated that there is a lack of state capacity, particularly at the institutional level. The major challenge they face to date pertains to community legal disputes, particularly those connected to farm trusts, farming co-operatives, and other similar arrangements. The above aligns with the Republic of South Africa [21] report, highlighting that the Land Claims Commission, which was tasked with managing land claims and the redistribution process, has been inefficient and dysfunctional.

\subsubsection{Land redistribution beneficiary selection process}

According to one government respondent (DRDLR1), selecting beneficiaries to ensure the rightful heirs for land redistribution remains a time-consuming and lengthy process. However, it can be acknowledged that this process is a necessary one; unfortunately, such processes still do not guarantee the prevention of situations whereby the inappropriate people benefit from the programme due to corrupt activities such as offering or accepting bribes.

\subsubsection{Land beneficiary resettlement support}

Another government respondent (DRDLR1) admitted that the government is still struggling to meet the demand for postsettlement support services required by the land beneficiaries. In this regard, the major stumbling blocks remain the lack of sufficient personnel (e.g., extension officers), resources (e.g., funds), and time to effectively deliver such services to the current and future land beneficiaries. The latter failings are supported by Jacobs et al. [44], who cite that the SA government has yet to successfully resolve the issues of posttransfer beneficiary support, such as a lack of extension services. One government official (DRDLR1) commented as follows:

"The state currently extends government feeding schemes in the form of soup kitchens within select communities of the GKM. The provision of food parcels and temporal accommodation to land claimants as a support mechanism is especially central in this pre-land-transfer stage."

\subsubsection{Monitoring and evaluation of the land redistribution} programme

Finally, both government respondents (MM1 and DRDLR1) concur that monitoring and evaluation is an obstacle for the land redistribution programme and the land reform programme as a whole. The fact that to date, there is no reliable monitoring and evaluation system holds some serious implications for the effective assessment of the success and/or failure rate of these programmes - as well as the ability to effect necessary and timely revisions thereof. Nevertheless, including this stumbling block on this list of significant state challenges comes as no surprise.

\subsection{The government supports that are given to beneficiaries at pre, during- and post-land-transfers}

The question seeks to establish the various kinds of support that the state extends to the land beneficiaries before, during, and after land transfer. A question was posed to the interviewees to list under each of the pre-determined headings (i.e., pre, during, and post-transfer of land) the types of support that the government provides to the land claimants as well as 
the official land beneficiaries of the land reform programme. The results are discussed as follows:

\subsubsection{Land redistribution programme pre-transfer of land phase}

Before the official transfer of land to the beneficiaries, the state initiated two feeding schemes that, although not directly linked to the land redistribution programme, actually assisted many of the current beneficiaries in alleviating food security issues. This was implemented through the receipt of food parcels and registration for the receipt of cooked meals at local community hall soup kitchens. Additionally, before the transfer of land, some beneficiaries received temporal accommodation, whilst others received blankets ("in case of a disaster"), and those who were eligible received government social security grants. Lastly, for those who received low-cost housing (which forms part of the land redistribution programme), the state had assisted them with groceries, mattresses, and temporal accommodation before being moved to the newly built housing units.

\subsubsection{Land redistribution programme during-transfer of land phase}

There is not much demand for support services within this stage of the land redistribution programme. The government continues to provide the needy claimants with food (through feeding schemes) and temporal accommodation as in the pre and post-transfer of land stages. This stage is typically characterized by varying waiting periods for the claimed land to be officially transferred to the awaiting claimants. According to the reports from the respondents, this can range from 2 to 10 years of waiting, with the average waiting period being 7.3 years. One state official (DRDLR1) is quoted as follows:

"To the best of my knowledge, during this phase of the programme, there actually might not be much land claimant support required by the beneficiaries - but I stand to be corrected."

\subsubsection{Land redistribution programme post-transfer of land phase}

Following the successful land transfer, some beneficiaries received assistance from various well-established private farmers who provided water resources and ploughing services. For instance, both the national and local governments have supported the beneficiaries in funding and/or training programmes. In particular, the Department of Agriculture is cited as having assisted them with funding. Furthermore, several forms of assistance in grant funding for farm equipment and/or farm mechanization are also available for beneficiaries to apply for from various state departments. However, even after land transfer, beneficiaries still receive food parcels once every three months and government social security grants (i.e., old-age pensions and/or child grants for those who have children). Finally, registration for groceries (food parcels) or soup kitchens is still ongoing even after land transfer. The above-quoted state official (DA1) is further quoted as follows:

"The availability of government feeding schemes, food parcels, as well as social security grants for those land beneficiaries who are still in need of these support services, continues even during this phase."

\section{CONCLUSIONS AND RECOMMENDATIONS}

Non-white citizens in South Africa were unjustly treated in land ownership during the apartheid regime, where all the fertile lands were apportioned to the white minority living only $7 \%$ to the non-white majority. The ANC government, having assumed office, promised to deal with the land ownership problem by instituting land reform policy to redistribute land wrongly acquired by the apartheid government to the rightful owners. However, the government has failed to implement the land redistribution programme since its introduction. This study has indicated issues such as land claim disputes and mediation process, reliance on the Willing-seller-willingbuyer Model adopted for the programme, lack of institutional capacity, cumbersome beneficiary selection Process, and the programme's monitoring and evaluation challenges preventing the achievement of the programme's objectives. These challenges have curtailed the socio-economic liberation of the programme's beneficiaries as promised by the government through the land reform policy. Therefore, it is recommended that the government institute measures to address these policy implementation challenges and make these lands available to the deserving beneficiaries. Their livelihood depends on the land because they will use it for cultivation and other income-generating activities. The study concentrated on the 3 departments tasked to implement the land redistribution programme. Future studies should explore the challenges of the programme implementation from the perspective of the programme's beneficiaries and contrast the findings.

\section{REFERENCES}

[1] Hall, R., Ntsebeza, L. (2007). The Land Question in South Africa. The Challenge of Transformation and Redistribution. Cape Town: HSRC Press, 1-26.

[2] Walker, C. (2003). The limits to land reform: Reviewing 'the land question'. Paper Presented at the African Studies/History seminar, University of Natal, Durban. https://scnc.ukzn.ac.za/doc/GEOG/Land_Claims/Walke r-C_Rethinking_the_land_question.pdf, accessed on June 15, 2019.

[3] Claassens, A., and Boyle, B. (2015). A promise betrayed: Polices and practice renew the rural dispossession of land, rights and prospects. Policy Briefing 124. Governance of Africa's Resources Programme.

[4] Republic of South Africa. (1997). White paper on South African land policy. Department of Land Affairs. Pretoria: Government Printers.

[5] Tarimo, A. (2014). African Land Rights Systems. Langaa RPCIG: ProQuest Ebook Central. http://ebookcentral.proquest.com/libuovs-

ebooks/detail.action?docID $=1732190$, accessed on March 4, 2019.

[6] Republic of South Africa. (1996). Constitution of the Republic of South Africa. Pretoria: Government Printers.

[7] Moosa, M. (2018). South Africans' views on land reform: Evidence from the South African Reconciliation Barometer. Reconciliation and Development Working Paper Series Number 05. Cape Town: Institute for Justice and Reconciliation.

[8] Ramaphosa, C. (2018). State of the nation address. Parliament of the Republic of South Africa. Cape Town. 
[9] Lahiff, E., Li, G. (2012). Land redistribution in South Africa: A critical review. World Bank, Washington DC. https://openknowledge.worldbank.org/handle/10986/27 168, accessed on August 3, 2019.

[10] Moseley, W.G., McCusker, B. (2008). Fighting fire with a broken teacup: A comparative analysis of South Africa's land-redistribution programme. Geographical Review. American Geographical Society, 98(3): 322-338. https://doi.org/10.1111/j.1931-0846.2008.tb00304.x

[11] Borras, S.M. (2003). Questioning market-led agrarian reform: Experiences from Brazil, Colombia, and South Africa. Journal of Agrarian Change, 3(3): 367-394. https://doi.org/10.1111/1471-0366.00059

[12] Bundy, C. (1979). The Rise and Fall of the South African Peasantry. Berkeley and Los Angeles: University of California Press.

[13] South African History Online. (2018). List of laws on land dispossession and segregation. https://www.sahistory.org.za/topic/list-laws-landdispossession-and-segregation, accessed on May 17 , 2019.

[14] Anseeuw, W., Mathebula, N. (2008). Land Reform and Development: Evaluating South Africa's Restitution and Redistribution Programmes. Research paper No. 2008/1, February. Published by the Postgraduate School of Agriculture and Rural Development, University of Pretoria, Pretoria 0002, South Africa.

[15] Beinart, W., Delius, P. (2013). 1913 land act: A longer history of dispossession. Mail \& Guardian. https://mg.co.za/article/2013-06-14-00-1913-land-act-alongerhistory-of-dispossession, accessed on May 14, 2019.

[16] World Bank. (1994). World Development Report 1994: Infrastructure for Development. New York: Oxford University Press.

[17] Department of Agriculture. (1995). White paper on agriculture. Pretoria: Department of Agriculture.

[18] African National Congress (ANC). (1994). The Reconstruction and Development Programme: A policy framework. Marshalltown: African National Congress

[19] Horneby, D., Kingwill, R., Royston, L., Cousins, B. (2017). Securing Land Tenure in Urban and Rural South Africa. Durban: University of KwaZulu-Natal Press.

[20] Alexander, A. (2016). Democracy dispossessed: Land, law and the politics of redistribution in South Africa. A Thesis Submitted in Partial Fulfillment of the Requirements for the Degree of Doctor of Philosophy in the Graduate School of Arts and Sciences, Columbia University.

[21] Republic of South Africa. (2017). Report of Working Group 2 on Land Reform, Redistribution, Restitution and Security of Tenure. Roundtable 5. Land Redistribution. Cape Town: Parliament of the Republic of South Africa.

[22] Kinsey, B. (2003). Comparative Economic Performance of Zimbabwe's Resettlement Models. In Roth, M., and Gonese, F. (2003) Delivering Land and Securing Rural livelihoods: Post-Independence Land Reform and Resettlement in Zimbabwe.

[23] Chimhowu, A.O. (2006). Tinkering on the Fringes? Redistributive Land Reforms and Chronic Poverty in Southern Africa. Working Paper 58, University of Manchester, Chronic Poverty Research Centre.

[24] López, R., Valdés, A. (2000). Fighting rural poverty in Latin America: New evidence of the effects of education, demographics, and access to land. Economic Development and Cultural Change, 49(1): 197-211. https://www.journals.uchicago.edu/doi/pdf/10.1086/452 497, accessed on September 15, 2019.

[25] Deininger, K., Binswanger, H.P. (1999). The evolution of the World Bank's land policy: Principles, experience, and future challenges. World Bank Research Observer, 14(2): 247-276, https://doi.org/10.1093/wbro/14.2.247

[26] Jeon, Y.D., Kim, Y.Y. (2000). Land reform, income redistribution, and agricultural production in Korea. Economic Development and Cultural Change, 48(2): 253-268. https://doi.org/10.1086/452457?journalCode=edcc

[27] Antwi, M.A., Oladele, O.I. (2013). Impact of the land redistribution for agricultural development (LRAD) projects on livelihoods of beneficiaries in Ngaka Modiri Molema District, South Africa. Journal of Human Ecology, 42(3): 273-281. https://doi.org/10.1080/09709274.2013.11906601

[28] Jayne, T.S., Yamano, T., Weber, T., Tschirley, M.T., Benfica, D., Chapoto, R., Zulu, A., Neven, B.D. (2002). Smallholder income and land distribution in Africa: Implications for poverty reduction strategies. California: MSU International Development.

[29] Dikgang, J., Muchapondwa, E. (2016). The effect of land restitution on poverty reduction among the Khomani San "Bushmen" in South Africa. South African Journal of Economics. $\quad 84(1)$ : $63-80$. https://doi.org/10.1111/saje.12088

[30] Chirwa, E.W. (2008). Land tenure, farm investments and food production in Malawi. Research Programme Consortium on Improving Institutions for Pro-Poor Growth. Discussion Paper Series Number 18, July.

[31] Byamugisha, F.F.K. (2013). Securing Africa's Land for Shared Prosperity: A Program to Scale up Reforms and Investment. World Bank Publications. https://ezproxy.ufs.ac.za (UFS library publications), accessed on March 10, 2019.

[32] Benin, S., Pender, J. (2002). Impacts of land redistribution on land management and productivity in the Ethiopian highlands. Socio-economics and Policy Research Working Paper 43. ILRI (International Livestock Research Institute), Nairobi, Kenya, p. 26.

[33] Turner, R.L. (2016). Lasting legacies: Contemporary struggles and historical dispossession in South Africa. Comparative Studies of South Asia, Africa, and the Middle East, 275-292. http://dx.doi.org/10.1215/1089201X3603343

[34] Binswanger, H.P., Elgin, M. (1988). What are the prospects for land reform? International Conference of Agricultural Economics, Buones Aires, pp. 739-754.

[35] Blumberg, B., Cooper D.R., Schindler, S.P. (2008). Business Research Methods. Second edition, London: McGraw- Hill Education.

[36] Creswell, J.W. (2007). Qualitative Inquiry and Research Design: Choosing among Five Approaches. 2nd ed. London: Sage.

[37] Creswell, J.W., Creswell, J.D. (2017). Research Design: Qualitative, Quantitative, and Mixed Method. Approaches, Los Angeles: Sage.

[38] Nieuwenhuis, J. (2007). Introducing Qualitative Research. In K. Maree (Ed.), First Steps in Research, Pretoria: Van Schaik, pp. 46-68.

[39] Garcia, D., Gluesing, J.C. (2013). Qualitative research 
methods in international organizational change research. Journal of Organizational Change Management, 26(2): 423-444. https://doi.org/10.1108/09534811311328416

[40] Merriam, S.B. (1988). Case Study Research in Education: A Qualitative Approach. San Francisco: Jossey-Bass.

[41] Babbie, E., Mouton, J. (2001). The Practice of Social Research. Cape Town: Oxford University Press.

[42] Downe-Wamboldt, B. (1992). Content analysis: Method, applications and issues. Health Care for Women International, 13(3): 313-321.
[43] Lahiff, E. (2007). Redistributive land reform and poverty reduction in South Africa. Working Paper for the Research Project on "Livelihoods after Land Reform." Programme for Land and Agrarian Studies, University of the Western Cape.

[44] Jacobs, P., Lahiff, E., Hall, R. (2003). Evaluating land and agrarian reform in South Africa: An occasional paper series. Final Report. Programme for Land and Agrarian Studies, University of the Western Cape. Cape Town, South Africa. 